\title{
Properties of Vitrified Rocky Flats TRUW with Different Waste Loadings
}

T. L. Eddy, J. W. Sears, J. D. Grandy, D. V. Miley, A. W. Erickson, R. N. Farnsworth and E. D. Larsen

Published July 1994

Idaho National Engineering Laboratory

EG\&G Idaho, Inc.

Idaho Falls, Idaho 83415

Prepared for the

U.S. Department of Energy

Assistant Secretary for Environmental Management

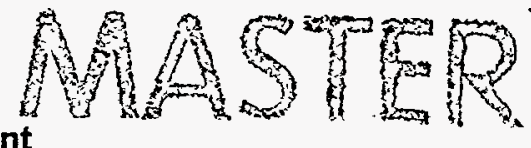
Under DOE Idaho Operations Office

Contract DE-AC07-76ID01570 


\section{DISCLAIMER}

This report was prepared as an account of work sponsored by an agency of the United States Government. Neither the United States Government nor any agency thereof, nor any of their employees, make any warranty, express or implied, or assumes any legal liability or responsibility for the accuracy, completeness, or usefulness of any information, apparatus, product, or process disclosed, or represents that its use would not infringe privately owned rights. Reference herein to any specific commercial product, process, or service by trade name, trademark, manufacturer, or otherwise does not necessarily constitute or imply its endorsement, recommendation, or favoring by the United States Government or any agency thereof. The views and opinions of authors expressed herein do not necessarily state or reflect those of the United States Government or any agency thereof. 


\section{DISCLAIMER}

Portions of this document may be illegible in electronic image products. Images are produced from the best available original document. 


\begin{abstract}
Leach rates, phase structures, and mechanical properties of simulated Rocky Flats Plant 1st and 2nd stage sludge vitrified in an arc melter are described as a function of waste to soil fraction and method of devitrification to produce the glass-ceramic waste form. Volatile, hazardous, and transuranic (TRU) surrogate metals were added to assess dissolution effects. Zirconia and titania were also added to confirm their ability as transuranic-surrogate getters.
\end{abstract}




\section{CONTENTS}

ABSTRACT $\ldots \ldots \ldots \ldots \ldots \ldots \ldots \ldots \ldots \ldots \ldots \ldots \ldots \ldots \ldots \ldots \ldots$ iii

INTRODUCTION $\ldots \ldots \ldots \ldots \ldots \ldots \ldots \ldots \ldots \ldots \ldots \ldots \ldots \ldots \ldots \ldots \ldots \ldots$

WASTE STREAM AND FORM COMPOSITION $\ldots \ldots \ldots \ldots \ldots \ldots \ldots \ldots \ldots$

PROCESSING METHODS $\ldots \ldots \ldots \ldots \ldots \ldots \ldots \ldots \ldots \ldots \ldots \ldots \ldots \ldots$

EXPERIMENTAL RESULTS $\ldots \ldots \ldots \ldots \ldots \ldots \ldots \ldots \ldots \ldots \ldots \ldots \ldots$

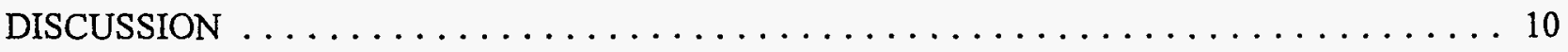

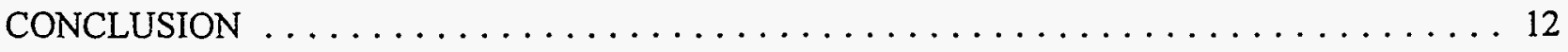

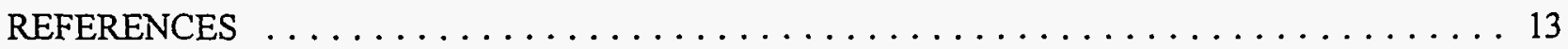

Figures

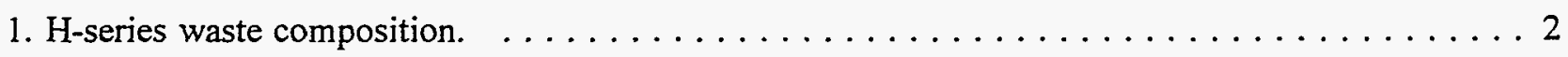

2. Schematic of bench-scale arc melter system. . . . . . . . . . . . . . . 3

3. IEB4/H-series slow-cooled waste form magnified $1000 \mathrm{X}-2000 \mathrm{X} . \ldots \ldots \ldots \ldots$

4. IEB4/H-series devitrified waste form magnified $1000 \mathrm{X}-2000 \mathrm{X} . \ldots \ldots \ldots \ldots$

5. PCT-A leach rates for the (a) slow-cooled and (b) devitrified samples (converted). $\ldots \ldots \ldots 8$

6. Bulk leach rate for IEB/IEB4 as $\mathrm{f}(\mathrm{Fe} 3 \mathrm{O} 4 / \mathrm{SiO} 2) . \ldots \ldots \ldots \ldots \ldots \ldots \ldots$

\section{Tables}

1. PCT-Method A 7-day leach rates in normalized $\mathrm{mg} / \mathrm{L} . \ldots \ldots \ldots \ldots \ldots \ldots$

2. Mechanical tests of different waste form materials. $\ldots \ldots \ldots \ldots \ldots \ldots \ldots$ 
-suo!̣snjouos

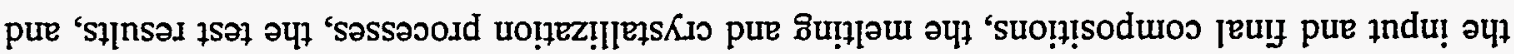

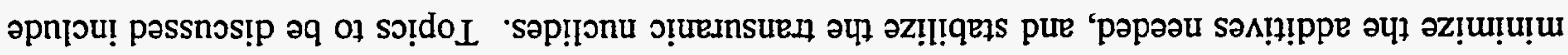

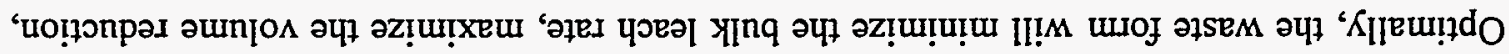

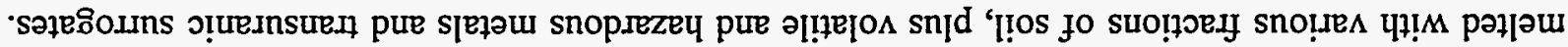

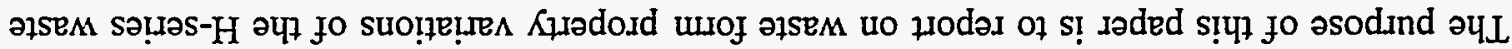

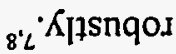

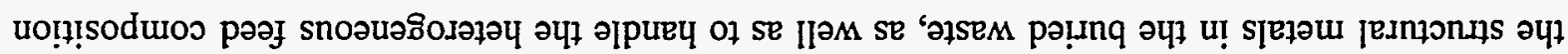

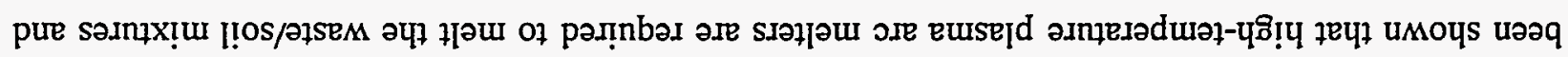

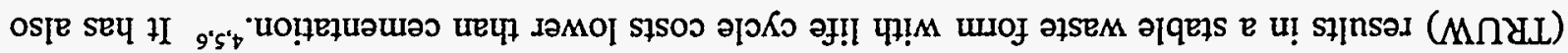

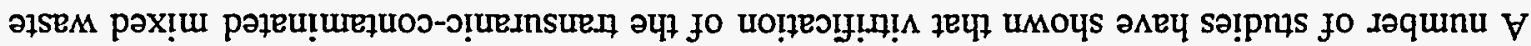

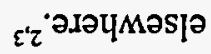

โ!Е]әр U! passnos!̣ '(

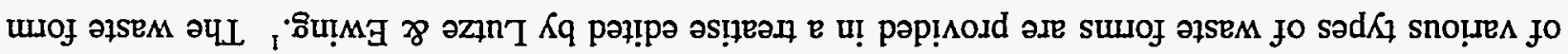

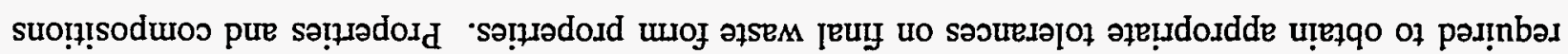

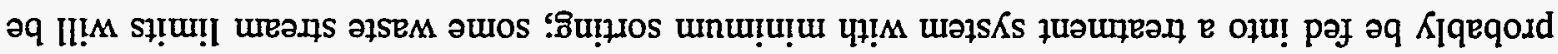

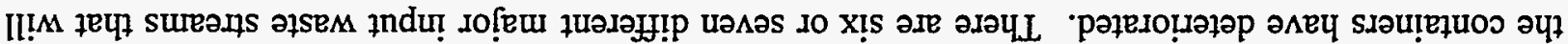

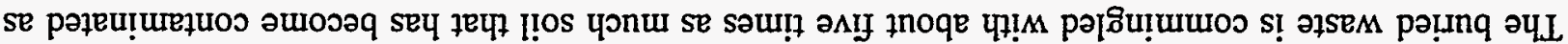

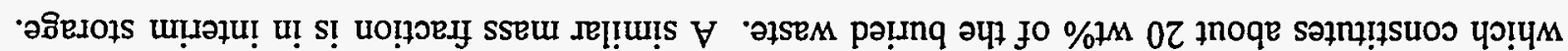

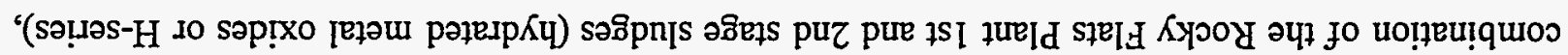

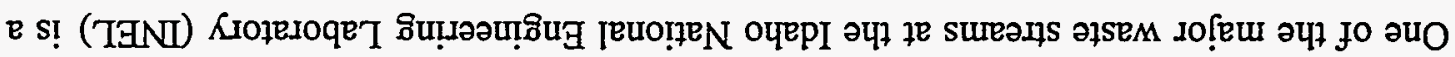

\section{NOILOกGOYLNI}

\section{s6uाреоา әฺุรeM ๆuәมән!}

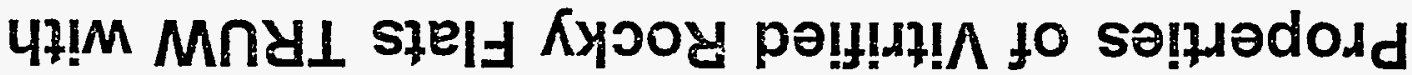




\section{WASTE STREAM AND FORM COMPOSITION}

The H-series waste stream may be either a 1st stage sludge $(\mathrm{H} 1)$ or a mix of 1 st and 2 nd stage sludges $(\mathrm{H} 2)$. The $\mathrm{H} 1$-series is studied here because its higher alkali concentration will have a greater effect on the tolerance limits of the leach rate. The composition of the H1-series waste (after dehydration of $60 \%$ as water) is shown in Fig. 1 as a function of wt $\%$ of soil. ${ }^{9}$

Soil fractions from $0 \%(\mathrm{H} 1-0)$ to $100 \%(\mathrm{Hl}$ 100) were investigated. $\mathrm{Cd}, \mathrm{Cr}, \mathrm{Pb}$ and $\mathrm{Zn}$ ( $1 \%$ each) were added as hazardous metals with various degrees of volatility. Cesium (1\%) was added to simulate the Cs137 nuclide; the $\mathrm{Ca}$ in the waste stream should be a reasonable $\mathrm{Sr}$ surrogate. Cerium and samarium (1\% each) were used as TRU surrogates. All were added as oxides.

The Synroc additives, zirconia and titania, had been found to act as getters for both transuranics ${ }^{10}$ and

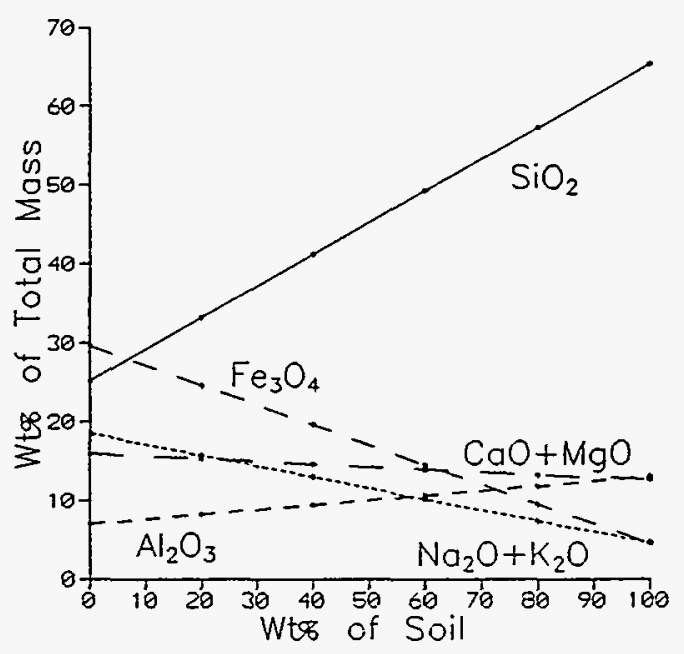

Fig. $1 \mathrm{H}$-series waste composition. TRU surrogates. " Five wt\% of each were added to give sufficient quantities for analysis, based on the aforementioned experiments. Later it was found that an additional $1-3 \% \mathrm{ZrO}_{2}$ dissolved into the melt from the refractory. $\mathrm{Ti}$ and $\mathrm{Zr}$ are Group $\mathrm{IVB}$ elements in the Periodic Table; hence, the waste form is designated IEB4. 


\section{PROCESSING METHODS}

The processing methods are thermal desorption and/or combustion of organics, melting in an arc melter, and a devitrification process. It was assumed that the waste had previously been oxidized. The appropriate mixture of oxides plus INEL soil was added to the melter in batch mode, melted in approximately one hour, and then cooled by various methods.

The arc melter system schematic is shown in Fig. 2. The melter is a water-cooled stainless steel crucible with a multiport top. Two 1-in. graphite electrodes are lowered through the top and are usually operated very close to, but above, the melt so that Joule heating dominates (>90\%). Typical operating conditions are 100-200 A and 150-250 V. The present tests were made without a cold cap of feed material. The crucible is either unlined, lined with a coating of Sauereisen cement, or lined using a 0.5 inch-wall ceramic pot made mostly of $\mathrm{ZrO}_{2}(54 \%), \mathrm{SiO}_{2}(27 \%), \mathrm{Al}_{2} \mathrm{O}_{3}(16 \%)$ and $\mathrm{CaO}$ (3.3\%).

Three cooling or devitrification methods are available. If fast-cooled $(\mathrm{FC})$, the melt remains in

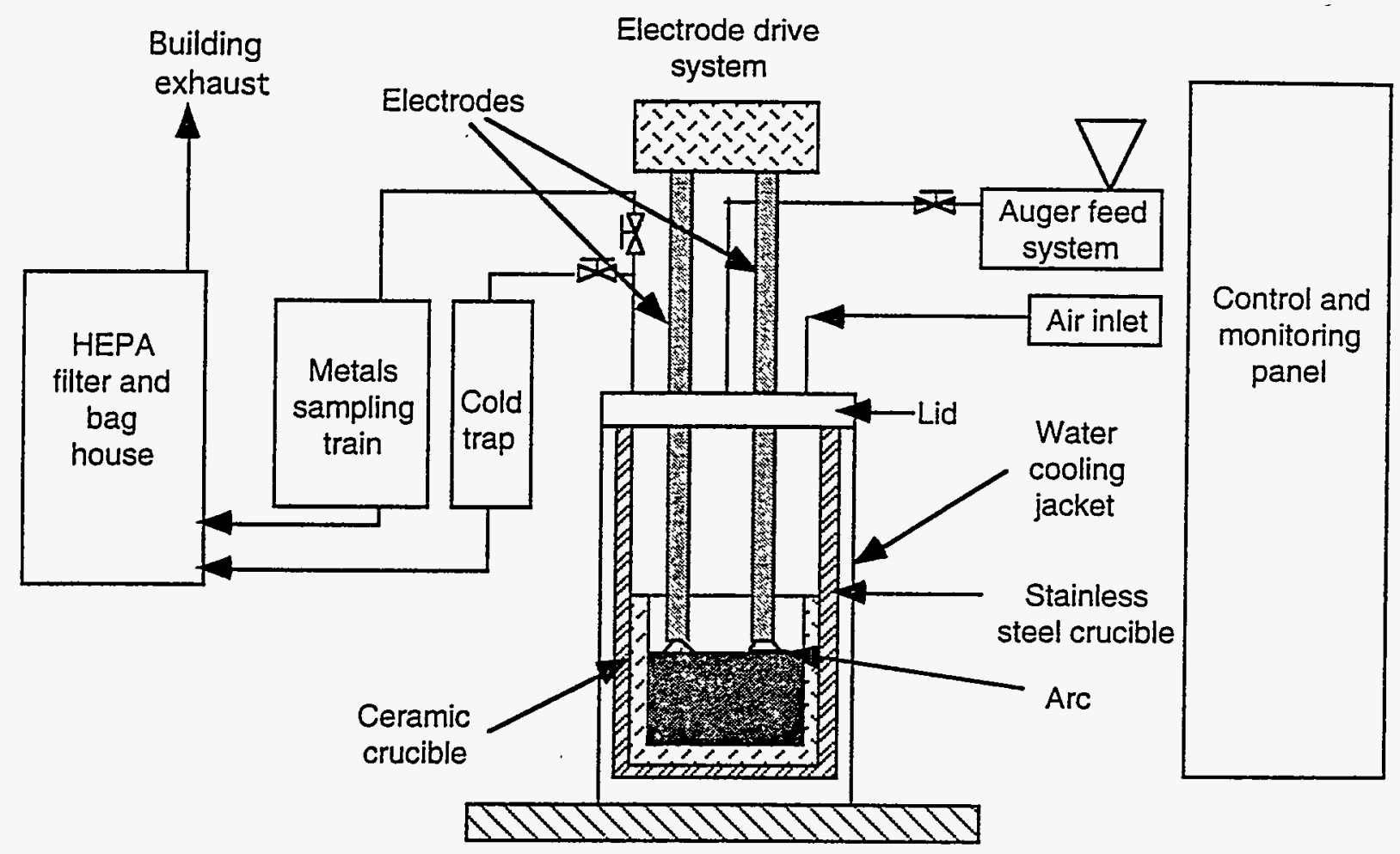

Lift table

Fig. 2 Schematic of bench-scale arc melter system. 
the water-cooled crucible lined with cement and cools through the $1250-1100^{\circ} \mathrm{C}$ crystallization range in about $5 \mathrm{~min}$. If slow-cooled (SC), the melt remains in the crucible, but the water is turned off and drained, lengthening the crystallization period to 10-20 min. The third method is devitrification (DV) by core drilling samples from a FC or SC process, remelting in quartz tubes in an oven at 1400 $1500^{\circ} \mathrm{C}$, then lowering to $1200^{\circ} \mathrm{C}$ for $16 \mathrm{~h}$, as per References 10 and 11 , then annealing at $600-700^{\circ} \mathrm{C}$, and cooling to room temperature. 


\section{EXPERIMENTAL RESULTS}

Photomicrographs from the scanning electron microscope (SEM) for the SC and DV waste forms at 1000X-2000X magnification are given in Figs. 3 and 4, respectively. The amount of soil goes from $0 \%$ on the upper left to $100 \%$ on the lower right corner in $20 \%$ increments. It is apparent that as soil was added, fewer and smaller crystals formed. The crystals are usually smaller in the SC case than in the DV case. For H1-100/SC (Fig. 3), the slag is very reducing, resulting in iron spheres. In the DV case, some additional oxidation probably occurred when remelting, thus no obvious iron spheres. Phase and overall compositions were determined using energy dispersive $x$-ray spectroscopy (EDXS).

The crystals in Figs. 3 and 4 are of similar phase composition, irrespective of soil fraction or cooling method. The lightest colored crystals are either zirconia or a $\mathrm{Zr}$-rich zirconolite, $(\mathrm{Ca}, \mathrm{Fe})_{1}(\mathrm{Ti}, \mathrm{Zr})_{3} \mathrm{O}_{7}$. A few at $100 \%$ waste loading contain a mainly-Cs nepheline, $(\mathrm{Cs}, \mathrm{Na}, \mathrm{K})(\mathrm{Fe}, \mathrm{Al}) \mathrm{SiO}_{4}$. The next lightest crystals or borders are either a $\mathrm{Zr}$-rich zirconolite adjacent to zirconia or a more complex mineral or solid solution that also includes ( $\mathrm{Al}, \mathrm{Cr}$ ). To get a better description, analysis is continuing. The $\mathrm{Mg} / \mathrm{Al} / \mathrm{Fe} / \mathrm{Cr}$ spinels are gray and blocky. Some spinels include ulvoespinels (because of the reducing conditions) which are less chemically stable. ${ }^{12}$ In Fig. 4, $\mathrm{Hl}-100 / \mathrm{DV}$, the light-gray blocky crystals are zircon, $\mathrm{ZrSiO}_{4}$. The feathery crystals are pyroxenes, and the background is composed of feldspathoids, feldspars and glass.

The TRU surrogates, $\mathrm{Ce}$ and $\mathrm{Sm}$, are almost totally in the $\mathrm{Zr}$-zirconolite phases with the balance in the glass/feldspar. Without a cold cap, essentially all of the $\mathrm{Cd}$ and $\mathrm{Pb}$ left the melt. Some $\mathrm{Zn}$, most of the $\mathrm{Cs}$, and essentially all of the $\mathrm{Cr}$ remained in the melt. The $\mathrm{Zn}$ and $\mathrm{Cr}$ are in the spinels and the Cs in the Cs-nepheline.

Leach tests and redox measurements were done by Cels-Laboratory Services, Corning, New York. The leach test used is the PCT, Method A, 7-day, static test of a crushed sample (74-149 $\mu \mathrm{m})$ in deionized water at $90^{\circ} \mathrm{C}$. Much data exists in the literature based on MCC-1 mass flux leach tests ${ }^{1}$ using 28-day, static, monolithic samples in deionized water at $90^{\circ} \mathrm{C}$. A method to convert from PCTA data to MCC-1 for glass-ceramics had been developed ${ }^{13}$ using actual densities, volume to surface area, and normalizing with overall compositions from EDXS measurements. The method was calibrated for glass-ceramics over more than 5 orders of magnitude, with results equivalent to the 

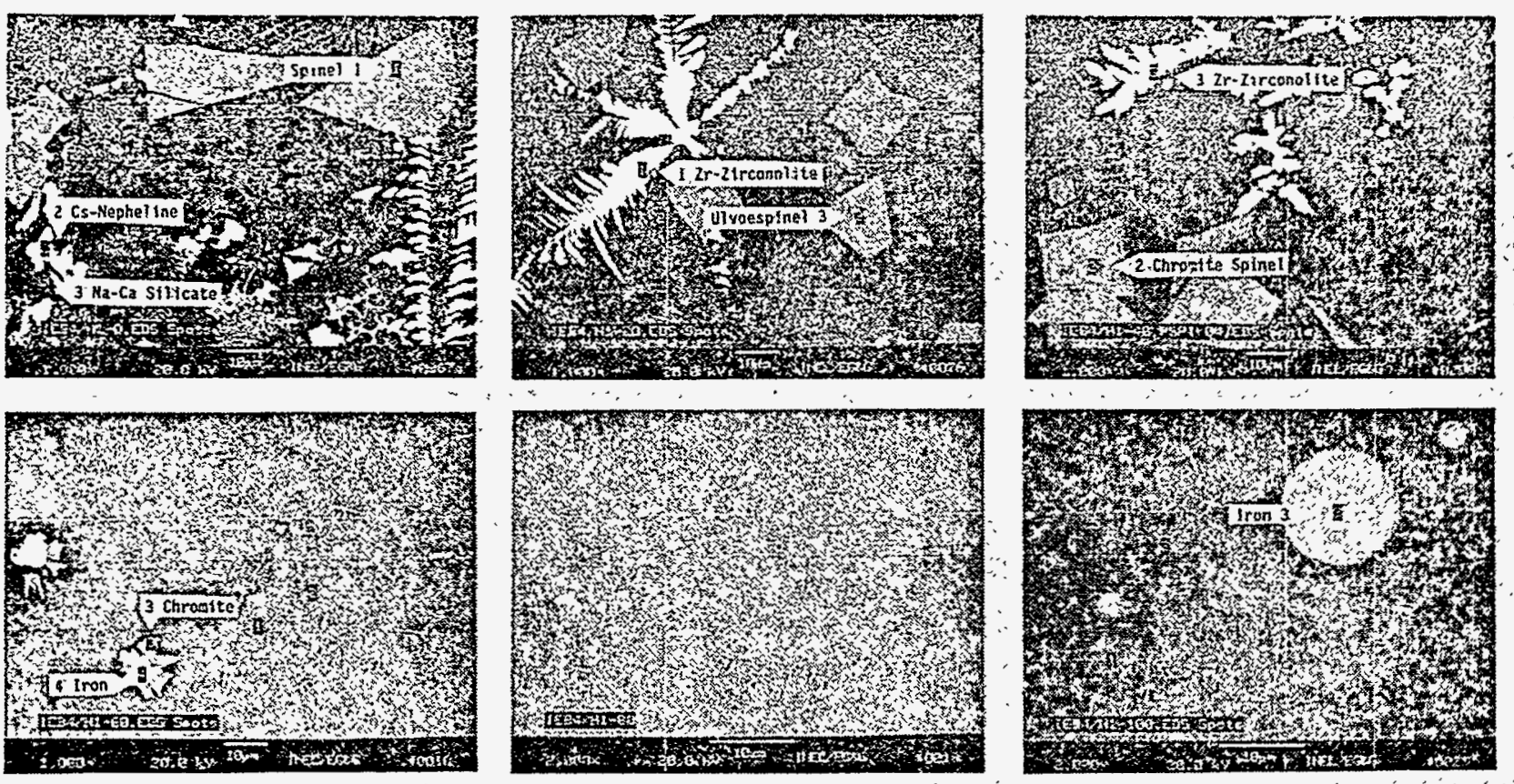

Fig. 3 IEB4/H-series slow-cooled waste form magnified 1000X-2000X.
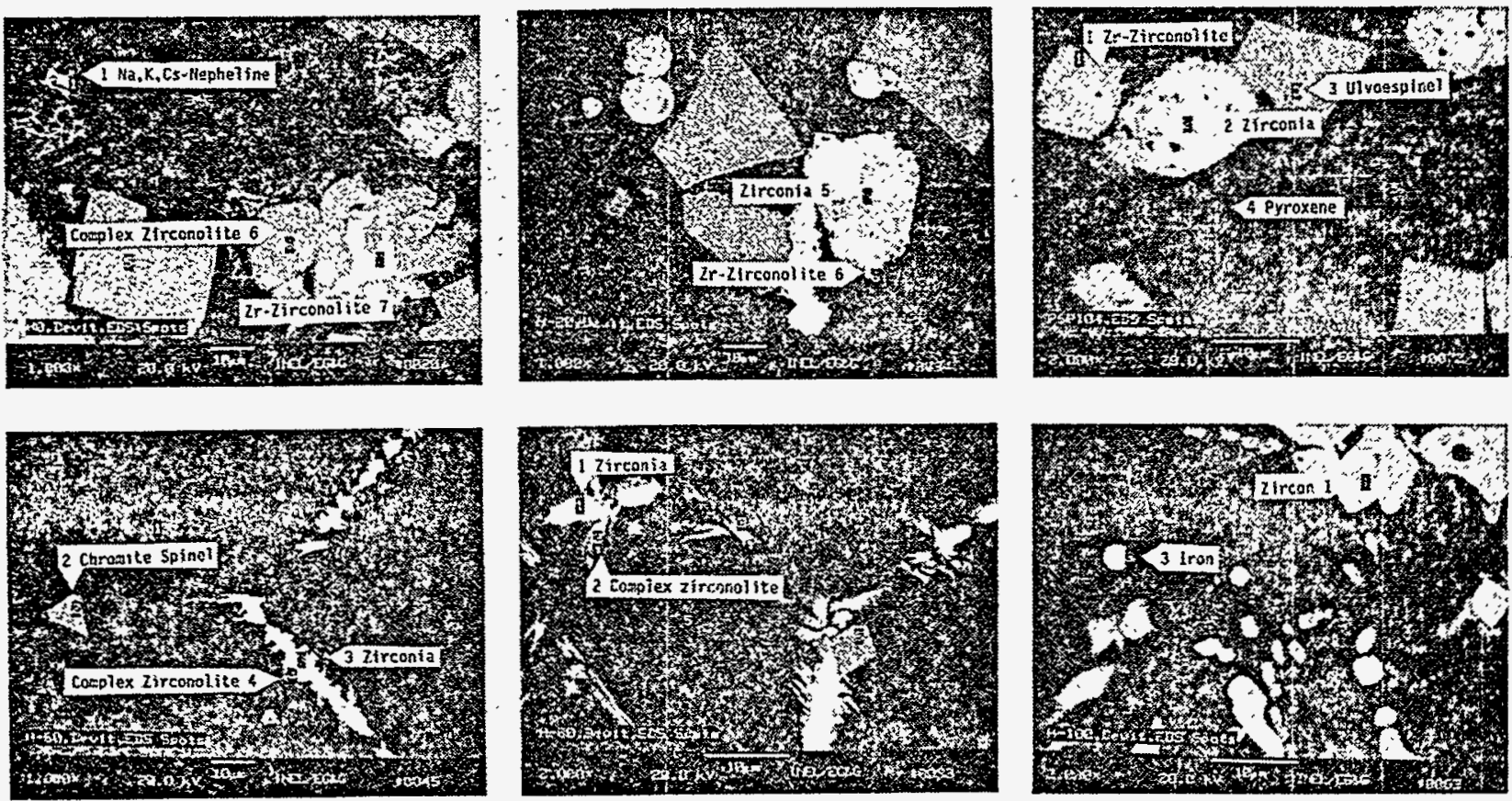

Fig. 4 IEB4/H-series devitrified waste form magnified 1000X-2000X.

scatter in the original data. Apparently other attempts to convert PCT-A to MCC-1 values for the more narrow range of interest for glass have been unsuccessful. 
Averaged PCT-A leach data from duplicate measurements are given in Table 1. Test methods were flame emission spectroscopy $(\mathrm{Cs}, \mathrm{Na}), \mathrm{ICP}(\mathrm{Ca}, \mathrm{Si})$ and ICP/MS $(\mathrm{Ce}, \mathrm{Sm})$. The data show that the alkali elements leach more than the alkaline earths, which leach more than the TRU surrogates. Table 1 also includes the equivalent Environmental Assessment (EA) Glass normalized mean leach rates reported by Jantzen, et al. ${ }^{14}$ for comparison. The leach rates for IEB4/H1-40 are approximately an order of magnitude lower than obtained for the EA Glass. Figure 5 shows the converted normalized PCT-A leach rates as a function of soil wt\%. Na leaches the most, with Cs second, followed closely by $\mathrm{Si}$ (the bulk rate indicator used here). $\mathrm{Ca}$ is a factor 10 lower, and $\mathrm{Ce}$ and $\mathrm{Sm} 10$ to 100 times lower yet. There does not appear to be any significant difference between the SC and the DV leach rate values. Apparently in the SC case, the crystals are of similar fraction but are smaller and more difficult to see. Prior studies ${ }^{15}$ of IEB with coarse and fine grain crystals reported a similar result.

The leach rates of $\mathrm{Na}, \mathrm{Cs}$, and $\mathrm{Si}$ decrease with increased soil fraction, but $\mathrm{Ca}, \mathrm{Ce}$, and $\mathrm{Sm}$ rates are statistically flat. Na-nepheline apparently increases leach rates in glass, but here the Csnepheline results in lower Cs leach rates than found in other glass-ceramics. ${ }^{\prime}$ Similar results were reported by others. ${ }^{16}$ Prior IEB studies had found a simple relationship between the bulk leach rate

Table 1. PCT-Method A 7-day leach rates in normalized $\mathrm{mg} / \mathrm{L}$.

\begin{tabular}{|c|c|c|c|c|c|c|c|}
\hline Species & $\mathrm{H} 1-0$ & $\mathrm{H} 1-20$ & $\mathrm{H} 1-40$ & $\mathrm{H} 1-60$ & $\mathrm{H} 1-80$ & $\mathrm{Hl}-100$ & EA Glass \\
\hline \multirow{2}{*}{ Si $\begin{array}{r}\text { SC } \\
\text { DV }\end{array}$} & $2.16 \mathrm{E}+01$ & $8.34 \mathrm{E}+02$ & $2.35 \mathrm{E}+02$ & $1.74 \mathrm{E}+02$ & $9.08 \mathrm{E}+01$ & $6.95 \mathrm{E}+01$ & \multirow[t]{2}{*}{$3.92 \mathrm{E}+03$} \\
\hline & $1.92 \mathrm{E}+03$ & $1.18 \mathrm{E}+03$ & $2.76 \mathrm{E}+02$ & $1.95 \mathrm{E}+02$ & $1.41 \mathrm{E}+02$ & $7.89 \mathrm{E}+01$ & \\
\hline \multirow{2}{*}{$\begin{array}{c}\mathrm{Ca} \\
\mathrm{DV}\end{array}$} & $3.89 \mathrm{E}+00$ & $6.67 \mathrm{E}+00$ & $8.53 E+00$ & $4.34 \mathrm{E}+00$ & $1.63 \mathrm{E}+01$ & \multicolumn{2}{|l|}{$5.93 E+01$} \\
\hline & $<1.73 \mathrm{E}-02$ & $3.74 E+00$ & $4.01 E+00$ & $3.43 E+00$ & $6.51 \mathrm{E}+00$ & $5.91 \mathrm{E}+01$ & \\
\hline \multirow{2}{*}{$\begin{array}{c}\mathrm{Na} \mathrm{SC} \\
\mathrm{DV}\end{array}$} & $2.87 \mathrm{E}+04$ & $5.55 \mathrm{E}+01$ & $2.50 \mathrm{E}+03$ & $1.63 E+03$ & $3.78 \mathrm{E}+02$ & $4.59 \mathrm{E}+02$ & \multirow[t]{2}{*}{$1.33 E+04$} \\
\hline & $2.21 E+04$ & $8.34 E+03$ & $7.54 \mathrm{E}+01$ & $1.63 E+03$ & $1.03 E+03$ & $4.98 E+02$ & \\
\hline \multirow{2}{*}{$\begin{array}{c}\mathrm{Cs} \mathrm{SC} \\
\mathrm{DV}\end{array}$} & $7.56 \mathrm{E}+04$ & $4.50 E+02$ & $9.54 \mathrm{E}+02$ & $5.49 E+02$ & $2.06 \mathrm{E}+02$ & \multicolumn{2}{|l|}{$6.07 \mathrm{E}+01$} \\
\hline & $5.49 E+04$ & $1.95 E+03$ & $1.40 \mathrm{E}+03$ & $5.80 E+02$ & $2.95 E+02$ & $9.26 \mathrm{E}+01^{\circ}$ & \\
\hline \multirow{2}{*}{$\begin{array}{c}\mathrm{Ce} S \mathrm{DV} \\
\mathrm{DV}\end{array}$} & $<2.04 \mathrm{E}-02$ & $1.00 \mathrm{E}+00$ & $2.05 \mathrm{E}-01$ & $1.62 \mathrm{E}+00$ & $1.22 \mathrm{E}-01$ & \multicolumn{2}{|l|}{$6.05 \mathrm{E}-01$} \\
\hline & $<4.76 \mathrm{E}-02$ & $1.28 \mathrm{E}-01$ & $7.59 \mathrm{E}+00$ & $3.69 \mathrm{E}+00$ & $9.56 \mathrm{E}-01$ & $2.02 \mathrm{E}-01$ & \\
\hline \multirow{2}{*}{$\begin{array}{c}\mathrm{Sm} S C \\
\mathrm{DV}\end{array}$} & $<5.66 \mathrm{E}-02$ & $1.43 \mathrm{E}+00$ & $1.92 \mathrm{E}-01$ & $4.76 \mathrm{E}-01$ & $1.43 \mathrm{E}-01$ & \multicolumn{2}{|l|}{$4.43 \mathrm{E}-01$} \\
\hline & $<6.90 \mathrm{E}-02$ & $1.47 \mathrm{E}-01$ & $1.06 \mathrm{E}+01$ & $5.34 \mathrm{E}+00$ & $9.82 \mathrm{E}-01$ & \multicolumn{2}{|l|}{$2.08 \mathrm{E}-01$} \\
\hline $\mathrm{Fe}^{2+} / \mathrm{Fe}^{\mathrm{tot}}$ & 0.38 & 0.71 & 0.93 & 0.96 & 0.93 & 0.86 & \\
\hline
\end{tabular}



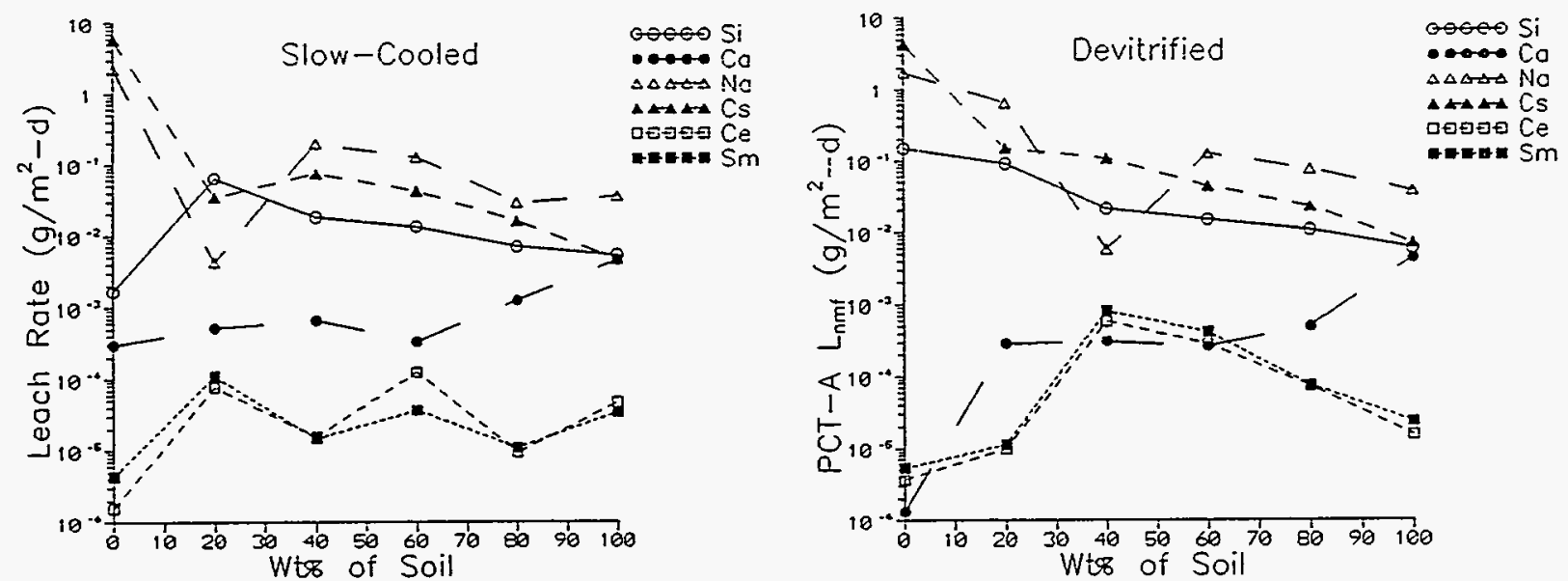

Fig. 5 PCT-A leach rates for the (a) slow-cooled and (b) devitrified samples (converted).

and the $\mathrm{Fe} / \mathrm{Si}$ ratio in the glass-ceramic for the A-series (average TRUW) as shown in Fig. 6. ${ }^{17}$ Also plotted and fitted in Fig. 6 are the SC and DV data for the IEB4/H1-series, using the Si rate as the bulk rate. Later IEB measurements, ${ }^{15}$ as well as some taken recently with the IEB/A-series ${ }^{18}$ indicate a shift down to the proximity of the IEB4 data is appropriate. The conclusion is that IEB and IEB4 data lie close together on this plot, possibly on a "universal" curve.

The redox ratio, $\mathrm{Fe}^{2+} / \mathrm{Fe}^{\text {total }}$, for the $\mathrm{SC}$ samples

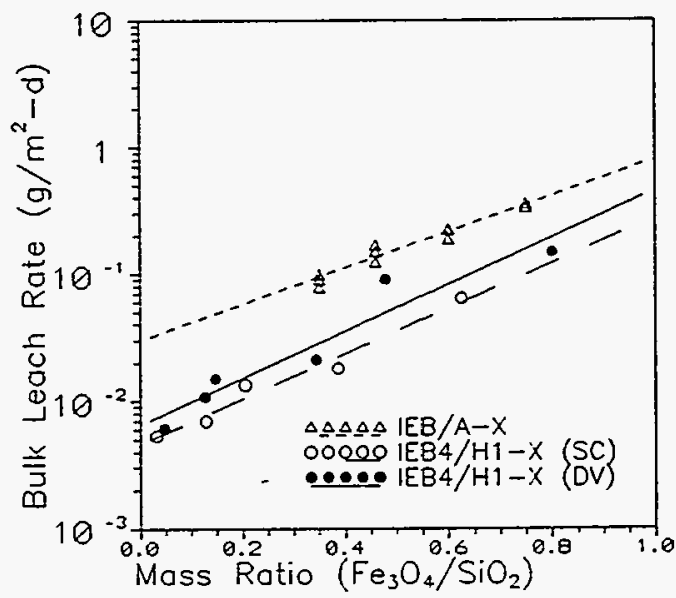

Fig. 6 Bulk leach rate for IEB/IEB4 as $\mathrm{f}\left(\mathrm{Fe}_{3} \mathrm{O}_{4} / \mathrm{SiO}_{2}\right)$. is given in Table 1. A value of unity is fully reduced (all $\mathrm{FeO}$ ). The values show that the high waste loadings are much more oxidizing. The DV samples were additionally oxidized during remelting.

Mechanical tests were made to compare the H1-series with other waste forms. Compressive strengths were measured using ASTM C39. Table 2 shows that the compressive strengths of the glasses and glass-ceramics are much higher than those of cement/concrete and all are higher than a typical requirement of $10 \mathrm{MPa}$, for a deep geologic repository. Respirable-fine tests were based on the impact test procedure of Jardine, Reedy and Mecham. ${ }^{19}$ Table 2 shows that the glass-ceramics generated no respirable fines under either the 10 or $15 \mu \mathrm{m}$ size criteria. 
Table 2. Mechanical tests of different waste form materials.

\begin{tabular}{|c|c|c|c|c|c|c|}
\hline \multirow[b]{2}{*}{ Waste Form } & \multirow{2}{*}{$\begin{array}{l}\text { Compressive } \\
\text { Strength (MPa) }\end{array}$} & \multicolumn{3}{|c|}{ - Respirable Fines (wt\%) } & \multirow[b]{2}{*}{ Smallest } & \multirow[b]{2}{*}{ Ref. } \\
\hline & & $<10 \mu \mathrm{m}$ & $<15 \mu \mathrm{m}$ & $<96 \mu \mathrm{m}$ & & \\
\hline$\overline{P C C}$ & $21-55$ & 0.32 & 0.40 & - & - & 1,18 \\
\hline SPC & $34-69$ & 0.15 & 0.33 & -- & -- & 18 \\
\hline BSG & 550 & 0.17 & - & - & - & 1 \\
\hline ASG/S-40 & 119 & None & None & 0.088 & $26 \mu \mathrm{m}$ & 18 \\
\hline IEB/A-40 & 430 & None & None & None & $>200 \mu \mathrm{m}$ & 18 \\
\hline IEB4/A-40 & 403 & None & None & 0.008 & $16 \mu \mathrm{m}$ & 18 \\
\hline IEB4/H-40 & 440 & None & None & None & $124 \mu \mathrm{m}$ & 18 \\
\hline
\end{tabular}




\section{DISCUSSION}

The effects of soil addition on the waste form are the following. When the waste loading is increased (soil is decreased), the phase structure is more crystalline, the redox state is more oxidizing, the bulk leach rate (based on $\mathrm{Si}$ ) increases, the Cs leach rate increases, but the TRU-surrogate leach rate is statistically flat. There is no significant difference between the leach rates of the slow-cooled (SC) and the devitrified (DV) waste forms over the range of soil added. The crystals are smaller in the slow-cooled waste form. This suggests that a special cooling process is probably not necessary for the $\mathrm{H}$-series waste stream.

Optimum soil loading to minimize the bulk leach rate, maximize the waste loading (volume reduction), and minimize variations in waste form structure appears to be $30-50 \mathrm{wt} \%$ soil (50-70 wt\% waste loading), or IEB4/H1-40. This is identical to the result obtained in prior IEB research for the average TRUW, i.e., IEB/A $-40 .^{2}$

On an absolute basis, the $\mathrm{Hl}$-series waste form quality is indicated by its ability to dissolve toxic metals or radionuclides. Mercury, chlorine, and sulfur will be in the offgas and require a secondary waste form, as will the extremely volatile heavy metals like $\mathrm{Cd}$. This will be similar to most other thermal treatments. $\mathrm{Zn}, \mathrm{Pb}$ and almost all of the $\mathrm{Cr}$ have been found dissolved in the very stable spinels. Most of the Cs is found dissolved in a mineral more stable than if it were in a borosilicate glass (BSG).

The effect of the Synroc additives ( $\mathrm{Ti}, \mathrm{Zr}$ ) is to create a much higher concentration of very stable phases than in IEB or BSG. Some perform as TRU-surrogate ( $\mathrm{Ce}, \mathrm{Sm}$ ) getters, as shown elsewhere for several actinides $(\mathrm{Pu}, \mathrm{Am}, \mathrm{Np}, \mathrm{Cm}),{ }^{10}$ as well as hosts for $\mathrm{Sr}(\mathrm{Ca})$. These crystals are surrounded by stable spinels, and less stable pyroxenes, feldspars and glass. The less stable phases are the hosts for the highest leaching species (Na, Cs, Si), even though their leach rate decreases with increasing glass fraction.

The bulk leach rate in glass-ceramics is misleading because much of the waste form is essentially insoluble, and would be partially excluded from leaching via the availability factor in performance assessments. As it is, the IEB/IEB4 bulk leach rate is about five times smaller, and most other leach rates are a factor of ten or more smaller, than typical BSG leach rates. ${ }^{1,17}$ The Cs leach 
rate is about five times larger than the IEB/IEB4 bulk rate, but the TRU-surrogate leach rate is more than 1000 times smaller. 


\section{CONCLUSION}

The IEB4/H1-40 waste form is extremely stable and a superior waste form for transuranic nuclides. The leaching characteristics did not vary significantly with the crystallization method, indicating that a special devitrification procedure is probably not required. The bulk properties of IEB4/H1-40 and IEB/A-40 are equivalent, with an apparently "universal" bulk leach rate function.

IEB4 provides additional mechanisms for long-term stability for the actinide and fission surrogates investigated. 


\section{REFERENCES}

1. W. Lutze \& R.C. Ewing (Eds.), Radioactive Waste Forms for the Future, North Holland, Amsterdam, 1988.

2. J.E. Flinn, et al., Annual Report on the TRU Waste Form Studies with Special Reference to IronEnriched Basalt, EGG-FM-5366, INEL/EG\&G Idaho, Idaho Falls, 1981.

3. G.A. Reimann, J.D. Grandy, T.L. Eddy \& G.L. Anderson, "Review of INEL Research on the IEB Waste Form," pp. 1083-1088, Spectrum '92, Am. Nuclear Soc., La Grange Park, II, 1992.

4. J.J. Schafer \& R.O. Schlueter, "Life-Cycle Cost Sensitivity of LLW and TRU Waste Transportation, Disposal, and Facility Decontamination and Decommissioning," pp. 1095-1100, Spectrum '92, Am. Nuclear Soc., La Grange Park, I, 1992.

5. D.F. Bickford, "Waste Vitrification Programs at Savannah River Site," Paper 5.5, Emerging Technologies in Hazardous Waste Management V, Am. Chemical Society Meeting, Atlanta, GA, Sept. 26-29, 1993.

6. D.M. Bennert, et al., "Demonstration of Vitrification of Surrogate F006 Wastewater Treatment Sludges," Paper SVIII-15-94, Am. Ceramic Soc. 96th Annual Meeting, Indianapolis, IN, April 24$28,1994$.

7. T.L. Eddy, B.D. Raivo \& G.A. Anderson, "Thermal Processing Systems for TRU Mixed Waste," pp. 1068-1076, Spectrum '92, Am. Nuclear Soc., La Grange Park, IL, 1992.

8. A.D. Donaldson, R.J. Carpenedo \& G.L. Anderson, "Melter Availability and R\&D Requirements for Processing TRU Mixed Waste," pp. 1077-1082, Spectrum '92, Am. Nuclear Soc., La Grange Park, IL, 1992.

9. J.D. Grandy, T. L. Eddy \& G. L. Anderson, TSA Waste Stream and Final Waste Form Composition, EGG-MS-1617, INEL/EG\&G Idaho, Idaho Falls, ID, January 1993.

10. J.G. Conley, P.V. Kelsey and D.V. Miley, "Investigations of the Properties of Iron-Enriched Basalt with $\mathrm{TiO}_{2}$ and $\mathrm{ZrO}_{2}$ Additions," pp. 302-309, Ceramics in Nuclear Waste Management, The American Ceramic Society, Chicago, Illinois, 1984.

11. G.A. Reimann and P.C. Kong, Improving Iron-Enriched Basalt with Additions of $\mathrm{ZrO}_{2}$ and TiO EGG-MS-10642, June 1993.

12. A.B. Harker, "Tailored Ceramics," p. 347, Radioactive Waste Forms of the Future, Ibid. 
13. T.L. Eddy \& J.D. Grandy, "PCT-A leach Rate Conversion," Emerging Technologies in Hazardous Waste Management VI, Am. Chemical Soc. Meeting, Sept. 19-21, 1994.

14. C.M. Jantzen, N.E. Bibler, D.C. Beam, C.L. Crawford \& M.A. Pickett, Characterization of the Defense Waste Processing Faciiity (DWPF) Environmental Assessment (EA) Glass Standard Reference Material (U), WSRC-TR-92-346, Rev. 1, Westinghouse Savannah River Co., Aiken, SC, June 1993.

15. J.M. Welch, R.L. Miller \& J.E. Flinn, Fuel and Core Storage Disposal Development, Report EGG-FM-6059, INEL/EG\&G Idaho, Idaho Falls ID, June 1983.

16. M.A. Lewis, D.F. Fischer \& C.D. Murphy, "Properties of a Glass Bonded Zeolite Monoliths," Am. Ceramic Soc. 96th Annual Meeting, Indianapolis, IN, April 24-28, 1994.

17. P.C. Kong, et al., Final Waste Form Option Scoping Studies for RWMC Wastes, EGG-WTD10363, INEL/EG\&G Idaho, Idaho Falls, ID, in publication.

18. G.L. Anderson, et al., "Comparison of Properties from Different Final Waste Forms for Mixed Wastes," Emerging Technologies in Hazardous Waste Management VI, Am. Chemical Soc. Meeting, Sept. 19-21, 1994.

19. L.J. Jardine, G.T. Reedy \& W.J. Mecham, "Respirable Fines Produced by Impacts of Simulated Alternative High-Level Waste Material," Scientific Basis for Nuclear Waste Management, Vol. 1, pp. 115-123, Materials Research Society, North-Holland Publ., New York, NY, 1982. 